\title{
Modulation of resolution of CCl4 induced liver cirrhosis following gadolinium chloride induced Kupffer cell blockade in an experimental model in male mice
}

\author{
Mona Gaber El-Hadidy ${ }^{1 *}$, Amr Medhat Abbas ${ }^{2}$, Fayza Elmenabawy ${ }^{3}$, Gad El Mawla Abd-Elaziz ${ }^{4}$ \\ 1 Assiatant lectuer of Medical Physiology, Faculty of Medicine, Mansoura University. \\ 2 Assiatant Professor of Medical Physiology, Faculty of Medicine, Mansoura University. \\ 3 Professor of Medical Physiology, Faculty of Medicine, Mansoura University. \\ 4 Professor of Medical Physiology, Faculty of Medicine, Mansoura University.
}

Received: 3 May 2016/ Accepted: 30 July 2016

*Correspondence author: eman_elhadidy82@yahoo.com

\begin{abstract}
Liver cirrhosis is a major cause of morbidity and mortality worldwide. There is evidence indicating that liver cirrhosis is dynamic and can be bidirectional, involving phases of progression and regression, along with major changes in the regulation of matrix degradation. There is also evidence that Kupffer cells participate in both fibrogenesis and fibrolysis. This study was aiming to determine the effect of inhibition of Kuppfer cells by gadolinium chloride $\left(\mathrm{GdCl}_{3}\right)$ on $\mathrm{CCl}_{4}$-induced liver cirrhosis in male balb-c mice. $\mathrm{GdCl}_{3}$ injected $\mathrm{i} / \mathrm{p}$ at dose of $10 \mathrm{mg} / \mathrm{kg}$ dissolved in normal saline, three times per week for 2 weeks, after injection of mice with $\mathrm{CCl}_{4} \mathrm{i} / \mathrm{p}$ at dose of $0.4 \mathrm{ml} / \mathrm{kg}(\mathrm{v} / \mathrm{v})$ with olive oil twice per week for 6 weeks. The rise in serum levels of alanine aminotransferase (ALT), aspartate aminotransferase (AST), and alkaline phosphatase (ALP) in $\mathrm{CCl}_{4}$-intoxicated mice was markedly suppressed by $\mathrm{GdCl}_{3}$ and histopathological changes were reduced and the expression of transforming growth factor $\beta$ (TGF- $\beta 1$ ) and Kupffer cells marker (CD68) were reduced in $\mathrm{GdCl}_{3}$ treated mice. The results of this study indicate that activated Kupffer cells are involved in both process of fibrogensis as they could release cytotoxic mediators outside the cell that cause hepatocyte damage and fibrinolysis through release of gelatinases enzyme.
\end{abstract}

Keywords: Liver cirrhosis, olive oil, cytotoxic mediators, gelatinases enzyme

\section{Introduction}

Liver cirrhosis is a frequent event which follows a repeated or chronic insult of sufficient intensity to trigger a "wound healing"-like reaction, characterized by excessive connective tissue deposition in extracellular matrix (ECM) (Domitrović et al., 2009).

Kupffer cells are resident macrophages of the liver which play an important role in its normal physiology and homeostasis (Roberts et al., 2007). Kupffer cells have long been considered as mostly scavenger cells responsible for removing particulate material from the portal circulation. 
Moreover, Kupffer cells may be involved in the pathogenesis of various liver diseases, as well as participating in the acute and chronic responses of the liver to toxic compounds (Kolios et al., 2006). There is an evidence indicating that liver cirrhosis is dynamic and can be bidirectional, involving phases of progression and regression, along with major changes in the regulation of matrix degradation. There is also an evidence that Kupffer cells participate in both fibrogenesis and fibrolysis (Kolios et al., 2006).

$\mathrm{GdCl}_{3}$ a rare earth metal, is a selective Kupffer cell toxicant that eliminates large Kupffer cells from the liver and blocks phagocytosis by liver macrophages in the attachment and engulfment phases. It has been extensively used in studies of hepatotoxic processes (Rose et al., 2001).

Therefore, the aim of the present work was to study the participation of Kupffer cells on the spontaneous resolution of hepatic cirrhosis and determine whether targeting Kupffer cell function using $\mathrm{GdCl}_{3}$, which specifically acts on Kupffer cells, could attenuate the progression of $\mathrm{CCl}_{4}$ induced hepatic cirrhosis.

\section{Material and methods:}

Experimental animals and treatment: A total of 40 male balb-c mice weighing $20 \pm 5 \mathrm{~g}$ were used and obtained from medical experimental research center (MERC), faculty of Medicine, Mansoura University, Egypt. Animals were apparently clinical healthy and were housed in stainless steel cages with wood shavings as breeding. Animal were accommodating to laboratory condition for 2 weeks before being experimented. Balb-c mice were maintained on balanced ration prepared in the MERC center. Water and feed were given adlibitium throughout the experiment. These mice were divided into four main groups:

Group A1: ( $\mathrm{n}=10$ mice) the control negative group mice which received $0.2 \mathrm{ml}$ olive oil intraperitoneal (i/p) twice per week for 6 weeks.

Group A2: ( $=30$ mice) injected with $\mathrm{CCl}_{4} \mathrm{i} / \mathrm{p}$ at dose of $0.4 \mathrm{ml} / \mathrm{kg}(\mathrm{v} / \mathrm{v})$ (Domitrovic et al., 2009) with olive oil twice per week for 6 weeks. These mice were sacrificed under anesthesia $72 \mathrm{hr}$ after last dose of $\mathrm{CCl}_{4}$

Group A3: ( $\mathrm{n}=10$ mice) injected with $\mathrm{CCl}_{4} \mathrm{i} / \mathrm{p}$ at dose of $0.4 \mathrm{ml} / \mathrm{kg}$ (v/v) (Domitrovicet al., 2009) with olive oil twice per week for 6 weeks, then injected with $\mathrm{GdCl}_{3} \mathrm{i} / \mathrm{p}$ at dose of $10 \mathrm{mg} / \mathrm{kg}$ (Rivera et al., 2001) dissolved in normal saline with three time per week for 2 weeks, and then were sacrificed under anesthesia $24 \mathrm{hr}$ after last dose of $\mathrm{GdCl}_{3}$.

Group A4: ( $\mathrm{n}=10$ mice) injected with $\mathrm{CCl}_{4} \mathrm{i} / \mathrm{p}$ at dose of $0.4 \mathrm{ml} / \mathrm{kg}$ ( $\mathrm{v} / \mathrm{v})$ (Domitrovic et al., 2009) with olive oil twice per week for 6 weeks, then left for spontaneous recovery without any treatment for another 2 weeks, and then were sacrificed under anesthesia.

\section{Analysis of plasma liver function markers:}

Blood was collected from each mice in a centrifuge tube and placed at water bath at $37 \mathrm{C}^{0}$. Serum was then separated by centrifugation at $3,000 \mathrm{rpm}$ for $5 \mathrm{~min}$. Serum samples were analyzed for alanine aminotransferase (ALT), aspartate aminotransferase (AST) alkaline phosphatase (ALP), serum albumin, total protein, urea concentration, blood glucose concentration and total bilirubin.

\section{Histological examination of liver:}

Light microscopic examination was performed in formalin-fixed and paraffin embedded specimens of the liver tissue, cut into 5- $\mu \mathrm{m}$ sections. Stained with $\mathrm{H} \& \mathrm{E}$ for morphological evaluation and Mallory's trichrome for the evaluation of fibrosis.

\section{Immunohistochemical analysis of liver:}

The livers were removed $0.5 \mathrm{~g}$ of liver was cut from each mice for immunohistochemical examination to measure the expression levels of Kupffer cells marker (CD68) and transforming growth factor $\beta$ (TGF $\beta 1)$. The standard immunohistochemical methods were adopted (Eissa and Shoman, 1998). The tissue sections were treated with microwave to produce unmasking of the epitopes of the antigen (Cattoreti et al 1992). The detection of tissues antigens by immunostaining is a two-step process. The first step is binding of the antigen with related primary antibody then visualisation of this reaction by a universal secondary antibody. The primary antibody measure the specificity of the reaction, while, the secondary antibody, with its linked enzyme, produces amplification of the reaction to increase of the sensitivity of the test. Universal systems used was the BiotinStreptavidin (BSA) system to visualise the markers (Hsu et al., 1981). Diaminobenzidine (DAB) was used as a chromogen since it produce a permanent preparation. Also, Hematoxylin counterstain was used. All slides were evaluated 
and classified semi-quantitativelyby means of a four-degree score according to (Jonker et al., 1994)

- (-) No staining

- Weakly, trace staining covering $<5 \%$ of hepatic lobules

- (+) Trace staining covering \%5-20 of hepatic lobules

- $\quad(++)$ Moderate staining covering \%20-50 of hepatic lobules

- $\quad(+++)$ Strong staining covering $>\% 50$ of hepatic lobules

\section{Statistical methods:}

All data are expressed as the mean \pm standard deviation. Statistical analyses were performed with SPSS software. Student's test was used to identify significant differences between the groups. $\mathrm{P}<0.05$ was considered to indicate a statistically significant difference.

\section{Results:}

\section{Plasma liver function markers:}

The results of the present study showed a significant increase $(\mathrm{P} \leq 0.001)$ in the serum concentrations of AST, ALT and ALP in cirrhotic mice (group A2) when compared with noncirrhotic mice (group A1) (Table 1). In the $\mathrm{GdCl}_{3}$ treated group (group A3) showed a significant decrease $(\mathrm{P} \leq 0.001)$ in AST, ALT and ALP when compared with cirrhotic group (Table 1). There was a significant decrease $(P \leq 0.001)$ in AST, ALT and ALP in group left for resolution of cirrhosis without any treatment (group A4) (Table 1).

\section{Table (1): The studied parameters of liver functions \\ Parameters}

\begin{tabular}{|c|c|c|c|c|c|c|c|c|}
\hline Parar & $\begin{array}{l}\text { AST } \\
(\mathbf{U} / \mathbf{L})\end{array}$ & $\begin{array}{l}\text { ALT } \\
(\mathbf{U} / \mathbf{L})\end{array}$ & $\begin{array}{l}\text { ALP } \\
(\mathbf{U} / \mathbf{L})\end{array}$ & $\begin{array}{c}\text { Total } \\
\text { bilirubin } \\
\text { (mg/dl) }\end{array}$ & $\begin{array}{c}\text { Total } \\
\text { plasma } \\
\text { protein } \\
(\mathrm{g} / \mathrm{dl})\end{array}$ & $\begin{array}{l}\text { Serum } \\
\text { albumin } \\
(\mathrm{g} / \mathrm{dl})\end{array}$ & $\begin{array}{l}\text { Serum urea } \\
(\mathbf{m g} / \mathbf{d l})\end{array}$ & $\begin{array}{l}\text { Blood glucose } \\
(\mathbf{m g} / \mathbf{d l})\end{array}$ \\
\hline Non-cirrhotic mice & $\begin{array}{c}22.33^{\mathrm{a} \pm} \\
2.07\end{array}$ & $\begin{array}{c}51.33^{\mathrm{a}} \pm \\
6.34\end{array}$ & $\begin{array}{c}150.80^{\mathrm{a}} \pm 3 \\
.023\end{array}$ & $\begin{array}{c}0.621^{\mathrm{a} \pm} \\
0.045\end{array}$ & $\begin{array}{c}6.68^{\mathrm{a}} \pm \\
0.28\end{array}$ & $\begin{array}{l}1.63^{\mathrm{a}} \pm \\
0.05\end{array}$ & $\begin{array}{c}2.23^{\mathrm{a}} \pm \\
0.06\end{array}$ & $\begin{array}{c}172.993^{\mathrm{a}} \pm \\
14.73\end{array}$ \\
\hline $\begin{array}{l}\text { Cirrhotic control } \\
\text { mice }\end{array}$ & $\begin{array}{c}136.33^{\mathrm{b}} \\
\pm 2.02\end{array}$ & $\begin{array}{c}213.50^{\mathrm{b}} \\
\pm 2.95\end{array}$ & $\begin{array}{c}256.50^{b} \pm 3 \\
.947\end{array}$ & $\begin{array}{l}0.78^{\mathrm{b}} \pm \\
0.03\end{array}$ & $\begin{array}{c}4.58^{\mathrm{b}} \pm \\
0.48\end{array}$ & $\begin{array}{c}0.857^{\mathrm{b}} \pm \\
0.04\end{array}$ & $\begin{array}{l}2.953^{\mathrm{b}} \pm \\
0.17\end{array}$ & $\begin{array}{c}119.007^{\mathrm{b}} \pm \\
2.56\end{array}$ \\
\hline $\begin{array}{l}\text { Cirrhotic mice } \\
\text { treated with } \mathbf{G d C l}_{3}\end{array}$ & $\begin{array}{l}59.80^{\mathrm{c}} \pm \\
2.74\end{array}$ & $\begin{array}{l}161.83^{\mathrm{c}} \\
\pm 2.59\end{array}$ & $\begin{array}{l}175.50^{\mathrm{c}} \pm 5 \\
.058\end{array}$ & $\begin{array}{c}0.78^{b} \pm \\
0.03\end{array}$ & $\begin{array}{c}5.22^{\mathrm{b}} \pm \\
0.53\end{array}$ & $\begin{array}{c}0.87^{\mathrm{b}} \pm \\
0.04\end{array}$ & $\begin{array}{c}2.95^{\mathrm{b}} \pm \\
0.15\end{array}$ & $\begin{array}{c}123.71^{\mathrm{b} \pm} \\
7.32\end{array}$ \\
\hline $\begin{array}{l}\text { Resolute cirrhotic } \\
\text { mice } \\
\text { P value }\end{array}$ & $\begin{array}{c}29.40^{\mathrm{a}} \pm \\
1.91 \\
\leq 0.001\end{array}$ & $\begin{array}{l}103.250 \\
{ }^{a} \pm 2.98 \\
\leq 0.001\end{array}$ & $\begin{array}{c}160.20^{\mathrm{a}} \pm 2 \\
.81 \\
\leq 0.001\end{array}$ & $\begin{array}{c}0.78^{\mathrm{b}} \pm \\
0.02 \\
\leq 0.05\end{array}$ & $\begin{array}{c}9.20^{\mathrm{c}} \pm \\
0.46 \\
\leq 0.001\end{array}$ & $\begin{array}{c}1.36^{\mathrm{ac}} \pm \\
0.04 \\
\leq 0.001\end{array}$ & $\begin{array}{c}2.67^{b} \pm \\
0.27 \\
\leq 0.05\end{array}$ & $\begin{array}{c}138.26^{\mathrm{b}} \pm \\
0.78 \\
\leq 0.05\end{array}$ \\
\hline
\end{tabular}

Data presented as means \pm SEM of ten mice in each group. Unshared letters between groups are the significance values at $\mathrm{P} \leq 0.05$.
Our results demonstrated significant decrease $(\mathrm{P} \leq 0.05)$ in the blood glucose in $\mathrm{CCl}_{4}$ treated group (group A2) when compared with noncirrhotic one (Table 1). In the $\mathrm{GdCl}_{3}$ treated group (group A3) and group left for resolution of cirrhosis without any treatment (group A4) showed non- significant $(\mathrm{P}>0.05)$ increase in blood glucose when compared with cirrhotic group (Table 1)

Our results showed a significant increase $(\mathrm{P} \leq$ 0.05) in serum level of urea in $\mathrm{CCl}_{4}$ treated group (group A2) when compared with non-cirrhotic one (Table 1). In the $\mathrm{GdCl}_{3}$ treated group (group A3) and group left for resolution of cirrhosis without any treatment (group A4) showed non-significant decrease $(P \leq 0.05)$ in serum level of urea when compared with cirrhotic group (Table 1).

Our results showed a significant increase $(\mathrm{P} \leq$ 0.05 ) in the serum level of total bilirubin in $\mathrm{CCl}_{4}$ treated group (group A2) when compared with non-cirrhotic group (Table 1). In the $\mathrm{GdCl}_{3}$ treated group (group A3) and group left for resolution of cirrhosis without any treatment (group A4) showed non-significant decrease $(\mathrm{P} \leq 0.05)$ in serum level of total bilirubin when compared with cirrhotic group (Table 1)

Our results demonstrate a significant decrease in the serum level of level of total protein $(\mathrm{P} \leq$ $0.05)$ and albumin $(\mathrm{P} \leq 0.001)$ in cirrhotic group (group A2) when compared with non-cirrhotic group (Table 1).In the $\mathrm{GdCl}_{3}$ treated group (group A3) showed non-significant $(\mathrm{P} \leq 0.05)$ increase in serum level of total protein and albumin when compared with cirrhotic group (Table 1). There was a significant increase $(\mathrm{P} \leq 0.001)$ in total protein, albumin in group left for resolution of cirrhosis without any treatment (group A4). 


\section{Histopathological changes of liver:}

Cirrhotic mice liver revealed that; the hepatocytes of the cirrhotic group showed diffuse degenerative change, centrilobularcoagulative necrosis, fatty infiltration, lymphocytic infiltration and micronodular cirrhosis with complete septal fibrosis when compared with non-cirrhotic group (Figure 1B). In the $\mathrm{GdCl}_{3}$ treated group revealed that the mature collagen fibers bridging structures present after $\mathrm{CCl}_{4}$ treatments became partially remodeled after the $\mathrm{GdCl}_{3}$ treatment period and decrease in fibrosis stage to stage IV when compared with cirrhotic mice (Figure 1C). Fibrotic lesions were still present in the livers of mice lifted for spontaneous reversion of liver cirrhosis but they were decrease in extent of fibrotic changes to stage II when compared with cirrhotic mice (Figure 1D).

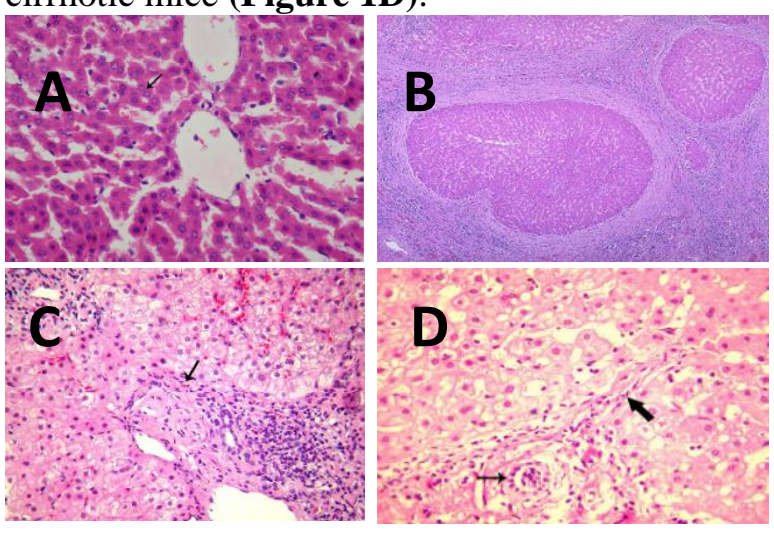

Fig (1): Histopathological examination of liver tissue stained with heamtoxylin and eosin $(\mathrm{H} \& \mathrm{E})$. A) Liver of group (A1) show normal hepatocytes with normal radial arrangement around central vein. B) Liver of group (A2) the cirrhotic liver shows the regenerative nodules of hepatocytes are surrounded by fibrous connective tissue that bridges between portal tracts. Within this collagenous tissue are scattered lymphocytes (H\&E). C) Liver of group (A3) showing grade IV fibrosis, dense intralobular fibrous band (arrow) with portal lymphocytic infiltration and massive necrosis of hepatocyte. D) Liver of group (A4) showed grade II fibrosis of periportal region in relation to bile duct (thin arrow), and incomplete portal to portal bridging (thick arrow), with mild lymphocytic infiltration.

In the current study the livers from control mice stained with Mallory trichrome stain showed traces of collagen only in the vascular walls (Figure 2A). Liver section from stained liver tissues of the $\mathrm{CCl}_{4}$ group showed multiple cirrhotic nodules and extensive fibrosis predominantly in the periportal areas (Figure 2B). In the $\mathrm{GdCl}_{3}$ treated group the Mallory trichrome stained section revealed blue fibrous tissue (Figure 2C). Mallory trichrome revealed bluestained fibrous tissue in the livers of mice lifted for spontaneous reversion of liver cirrhosis (Figure 2D).
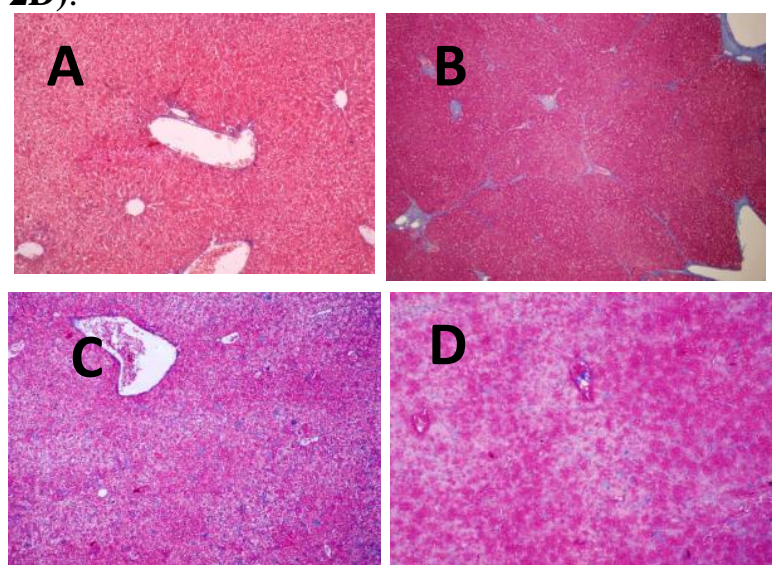

Fig (2): Histopathological examination of liver tissue stained with Mallory trichrome. A) Liver of group (A1) show normally bluish coloration of fibrous connective tissue restricted in portal area. B) Liver of mice group (A2) showing extensive bluish coloured fibrous tissue extended allover hepatic lobules. C) Liver of group (A3) still show bluish stained fibro-collagenous tissue scattered all over hepatic lobules. D) Liver of group (A4) showed moderate bluish stained fibrous tissue forming islets of fibro-collagenous tissue in hepatic lobules.

\section{Immunohistochemical analysis of liver:}

The results of this work showed a strong staining reaction (+++) of liver against TGF- $\beta_{1}$ in cirrhotic liver when compared to non-cirrhotic group (Figure 3B). In $\mathrm{GdCl}_{3}$ treated group showed a moderate staining $(++)$ of liver tissue against TGF- $\beta$ monoclonal antibodies in this group when compared to cirrhotic one (Figure 3C). Liver belongs to group of spontaneous reversion of cirrhosis showed faint staining (+) against TGF- $\beta$ antibody in resoluted mice when compared with cirrhotic one (Figure 3D).

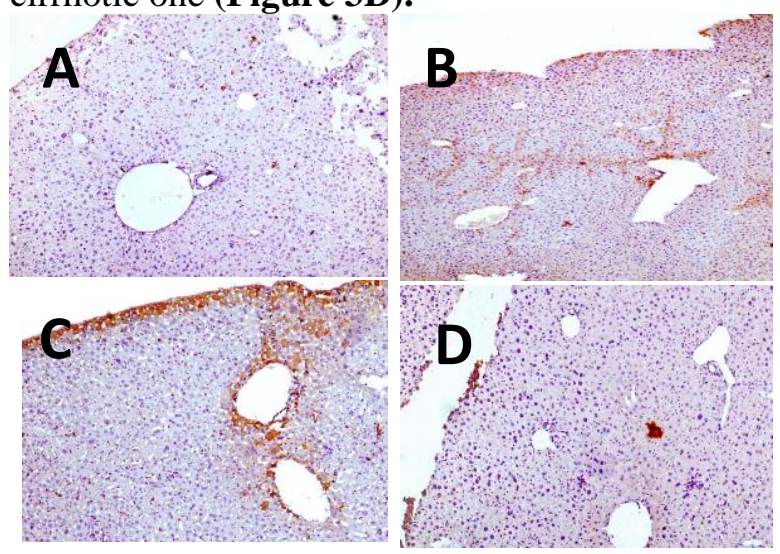


Fig (3): Immunohistochemical staining of liver tissue for TGF $\beta_{1}$ monoclonal antibody. A) Liver of control group (A1) showing negative staining (-) against TGF $\beta_{1}$ monoclonal antibody. B) Liver of group (A2) treated with $\mathrm{CCl}_{4}$ showing strong staining (+++) against TGF $\beta 1$ monoclonal antibody. C) Liver of group (A3) treated with $\mathrm{GdCl}_{3}$ showing moderate staining reaction $(++)$ against TGF $\beta 1$ monoclonal antibody immune-reaction allover liver tissue. D) Liver of resloute subgroup (A4) showing trace staining (+) against TGF $\beta 1$ monoclonal antibody.

The effect of $\mathrm{GdCl}_{3}$ on Kupffer cells was investigated by staining liver slices with anti-ED1 (CD68). The cirrhotic liver showed a strong staining reaction $(+++)$ of liver against CD68 antibodies when compared with non-cirrhotic mice (Figure 4B). $\mathrm{In}_{\mathrm{GdCl}}$ treated group showed no staining (-) of liver tissue against CD68 monoclonal antibodies when compared to cirrhotic one (Figure 4C).Liver belonges to group of spontaneous reversion of cirrhosis show strong staining (+++) against CD68 antibodies when compared with cirrhotic one (Figure 4D).

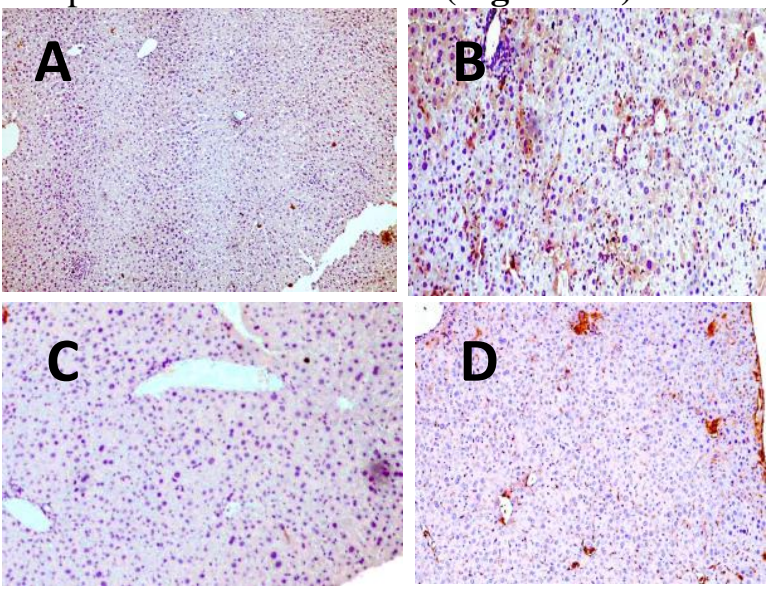

Fig (4): Immunohistochemical staining of liver tissue for CD68 monoclonal antibody. A) Liver of control group (A1) show normal staining reaction against CD68 monoclonal antibody. B) Liver of group (A2) treated with $\mathrm{CCl}_{4}$ show strong staining reaction (+++) against CD68 monoclonal antibody. C) Liver of group (A3) treated with $\mathrm{GdCl}_{3}$ showing no staining reaction (-) against CD68 monoclonal antibody. D) Liver of resloute group (A4) showing strong staining reaction (+++) against CD68 monoclonal antibody.

\section{Discussion:}

$\mathrm{GdCl}_{3}$ a rare earth metal, is a selective Kupffer cell toxicant that eliminates large Kupffer cells from the liver and blocks phagocytosis by liver macrophages in the attachment and engulfment phases. It has been extensively used in studies of hepatotoxic processes (Rose et al., 2001). The goal of this study was to determine effect of inhibition of Kupffer cells activity by $\mathrm{GdCl}_{3}$ in $\mathrm{CCl}_{4-}$ induduced liver cirrhosis in balb-c mice.

AST is localized in cellular cytoplasm while ALT is both cytosolic (20\%) and mitochondrial (80\%) (Giannini et al., 2005). AST is also diffusely represented in the heart, skeletal muscle, kidneys, brain and red blood cells, and ALT has low concentrations in skeletal muscle and kidney; therefore, an increase in ALT serum levels is more specific factor for liver damage.ALP catalyzes the hydrolysis of phosphomonoesters at alkaline $\mathrm{pH}$. ALP is an ectoenzyme of the hepatocytes plasma membrane (Moss and Handerson, 1999; Gitnick et al., 1992). The results of the present study showed a significant increase in the serumconcentrations of AST, ALT and ALP in cirrhotic mice in agreement with Robert and Hustead (2011). The increase of these enzymes could be attributed to the damaged structural integrity of hepatic cells and increased permeability hepatocyte membrane which mediated by $\mathrm{CCl}_{4}$ toxicity lead to release of these enzymes into the circulation (Paduraru et al., 1996).

Our results demonstrated significant decrease in the blood glucose in $\mathrm{CCl}_{4}$ treated groupin agreement withAlthnaian et al. (2013). This can be due to disturbance in carbohydrate metabolism. It has been known that hypoglycaemia is main feature of $\mathrm{CCl}_{4}$ toxicity (Mion et al., 1996). Yadav et al. (2008) have reported that administration of $\mathrm{CCl}_{4}$ caused decreased hepatic glycogen content. Moreover, AL-Malki et al., 2013, explained this decrease in glucose level is due to impaired gluconeogenesis and glycogenolysis in the cirrhotic liver.

Our results showed a significant increase in serum level of urea in $\mathrm{CCl}_{4}$ treated group in agreement with Reyes-Gordillo et al. (2007); Al-Malki et al. (2013) and Mohamed et al. (2014). The increased in urea level could be explained by damage of kidney by $\mathrm{CCl}_{4}$ (Zimmerman et al., 1983).

Serum bilirubin had been reported to be the most sensitive indicator for the functional integrity of the liver and severity of necrosis (Shukla and Bhatia, 2010). Our results showed a significant increase in the serum level of total bilirubin in $\mathrm{CCl}_{4}$ treated group in agreement with Fang et al. (2004). This increase in the levels of serum bilirubin due to liver damage as the liver is responsible for clearing the blood of bilirubin (Shukla and Bhatia, 2010). 
Our results demonstrate a significant decrease in the serum level of level of total protein and albumin in cirrhotic group in agreement with Navarro and Senior (2006). This can be due to decrease in the functioning mass and synthetic function of liver in liver cirrhosis (Lee, 2003). The capacity of liver microsomes to incorporate amino acids is depressed, causing a generalized inhibition of protein synthesis. These changes result in rapid loss of the ability of liver to synthesize albumin (Rothschild et al., 1972).The lowered level of total protein in the serum indicates the severity of hepatocellular damage (Aniya et al., 2005).

Moreover, histopathological examinations of cirrhotic mice liver revealed that; the hepatocytes of the cirrhotic group showed diffuse degenerative change, centrilobularcoagulative necrosis, fatty infiltration, lymphocytic infiltration and micronodular cirrhosis with complete septal fibrosis when compared with non-cirrhotic group. These results are in accordance with Noyan et al. (2006). In the current study the livers from control mice stained with Mallory trichrome stain showed traces of collagen only in the vascular walls. Liver section from stainedliver tissues of the $\mathrm{CCl}_{4}$ group showed multiple cirrhotic nodules and extensive fibrosis predominantly in the periportal areas. These results were in agreement with (Domitrović et al., 2009). These changes may be due to activation of Kupffer cells by $\mathrm{CCl}_{4}$, this activated cells will release fibrogenic cytokines which activate HSCs and portal fibroblasts to produce myofibroblasticphenotyp cells which secreted a large amount of collagen type I and III, therefore, the terminal outcome of liver cirrhosis is the formation of nodules with bridge of fibrosis in between (Guyot et al., 2006).

Treatment with $\mathrm{GdCl}_{3}$ produces a significant decrease in AST, ALT and ALP when compared with cirrhotic group, accompanied by decrease stage of liver fibrosis to stage IV by histopathological examination. But in spontaneous resoluted group which not treated with $\mathrm{GdCl}_{3}$ show more decrease in AST, ALT and ALP when compared with cirrhotic group which confirmed by more decrease in fibrotic stage to stage II with decrease deposition of collagen by Mallory trichrome stain. This gives an additional support that Kupffer cells are important in both process of fibrogensis and fibrinolysis.

The initiation and maintenance of fibrogenesis in the liver is characterized by two processes. The former is characterized by the activation and transformation of HSCs to myofibroblasts resulting in increased production of collagen types I and III. Maintenance of fibrosis involves decreased production of matrix metalloproteinase (MMPs) and increased production of specific tissue inhibitors of matrix metalloproteinase (TIMPs) or non-specific metalloproteinase inhibitors ( $\alpha_{1}$-antitrypsin) (Kolios et al., 2006).

Moreover, Kupffer cells are involved in processes via the production of cytokines and growth factors that induce stellate cell myofibroblastic transformation and also via regulation of the production of metalloproteinase and their inhibitors (Xidakis et al., 2005). Another mechanism is the production of gelatinases by Kupffer cells; this gelatinase degrades collagen type IV (Kolios et al., 2006).

In parallel with the above information, the present study revealed that, the hepatotoxic agent, $\mathrm{CCl}_{4}$, leads to pronounced increment in serum proinflammatory fibrogenic cytokine, TGF- $\beta 1$ in agreement with Hsieh et al. (2011).TGF- $\beta 1$ is considered as the main cytokine that drives fibrosis in various animal models of hepatic damage, including alcoholic liver fibrogenesis, schistosomiasis and $\mathrm{CCl}_{4}$-induced fibrosis, and one of the major factors involved in fibrosis in patients with chronic liver disease. Kupffer cellderived TGF- $\beta 1$ has been suggested to drive stellate cell transformation and to induce production of collagen and proteoglycans by these cells (Kolios et al., 2006).

The result of this work showed a moderate staining of liver tissue against TGF- $\beta$ monoclonal antibodies in group treated with $\mathrm{GdCl}_{3}$ when compared to cirrhotic one. Although stellate cells are capable of producing TGF- $\beta$, many studies indicate that increased expression of TGF- $\beta$ mRNA in Kupffer cells isolated from rats with alcoholic fibrosis precedes expression in stellate cells (Tsukamoto et al, 1995). Therefore, destruction of Kupffer cells with $\mathrm{GdCl}_{3}$ prevents the release of this proinflammatory and profibrogenic cytokine from Kupffer cells only not from stellate cells (Rivera et al., 2001). Therefore, in spite of inhibition of Kupffer cells the liver tissues still show staining against TGF- $\beta$. Moreover, liver macrophages are thought to be the main cell involved in phagocytosis; there are many evidences confirm that both stellate cells and Kupffer cells express the phosphatidyl serine receptor suggesting that both cell types are able to phagocyte hepatocytes apoptotic bodies (Chakraborty et al., 2012). Phagocytosis of these apoptotic bodies by stellate cells has also been 
implicated in fibrogenesis through increase expression of TGF- $\beta 1$ (Canbay et al., 2003). In the result of present work the liver show faint staining against TGF- $\beta$ antibody in resoluted mice when compared with cirrhotic one. This TGF- $\beta$ secrete from Kupffer cells during cirrhosis that constitutes a potent mitogenic factor for stellate cells (Lotersztajn et al., 2005).Therefore, decrease expression of TGF- $\beta$ will accompanied with decrease collagen deposition in liver and this supported histologically in the current work by decrease in stage of fibrosis.

To elucidate the function of macrophages in liver cirrhosis, a specific macrophage marker, CD68, has been used to monitor macrophage activation (Thomas et al., 2015). Our results showed a strong staining reaction of liver against CD68 antibodies in cirrhotic mice in agreement with Liu et al. (2010) who observed increase expression of CD68-positive macrophages in hepatic sinusoids and adjacent to fibrotic septa in liver cirrhosis. In normal liver CD68-positive macrophages were present in hepatic sinusoids and were at very low levels. In liver injury like in $\mathrm{CCl}_{4}$ could be associated with activation of Kupffer cells and trigger migration of macrophage into hepatic cords in which these macrophages stimulate fibrosis by secreting fibrogenic cytokines (Fallowfield et al., 2007).

The effect of $\mathrm{GdCl}_{3}$ on Kupffer cells was investigated by staining liver slices with CD68, the livershow no staining against this antibody. Koop et al., 1997 showed that $\mathrm{GdCl}_{3}$ eliminated $80 \%$ of a Kupffer cells receptor (CD68). $\mathrm{GdCl}_{3}$ is destroying exclusively activated Kupffer cells, by damaging the plasma membrane. The action of $\mathrm{GdCl}_{3}$ has a biphasic pattern, during an initial phase, it inhibits phagocytosis by Kupffer cells, whereas, during a later phase it induces the destruction of large Kupffer cells (Koudstaal et al., 1991). While, in the present work the liver show strong staining against CD68 antibodies in resoluted groupwhen compared with cirrhotic one.

\section{References}

Al-Malki Abdulrahman L. Abo-Golayel Mohamed Kamel, Abo-Elnaga3Gamal and Al-Beshri Hassan (2013):Hepatoprotective effect of dandelion (Taraxacumofficinale) against induced chronic liver cirrhosis. Journal of Medicinal Plants Research Vol. 7(20), pp. 1494-1505, 25.

Baijun Fang, Mingxia Shi, Lianming Liao, Shaoguang Yang, Yuhao Liu, and Robert Chunhua Zhao (2004): Systemic Infusion of FLK1Mesenchymal Stem Cells Ameliorate Carbon TetrachlorideInduced Liver Fibrosis in Mice

Canbay A, Feldstein AE, Higuchi H, et al. (2003): Kupffer cell engulfment of apoptotic bodies stimulates death ligand and cytokine expression. Hepatology 38:1188-98.

Cattoreti G, Becker, HG and Key G (1992): Monoclonal antibodies against recombinant parts of Ki-67 (MIB-1 and MIB-3) detect proliferating cells in microwave-processed formalin-fixed paraffin sections. J. Pathol.; 168: 357-363.

Cheng Liu, Qing Tao,Mingyu Sun, Jim Z Wu,Wengang Yang, Ping Jian,JinghuaPeng, Yiyang Hu, Chenghai Liu, and Ping Liu (2010):Kupffer cells are associated with apoptosis, inflammation and fibrotic effects in hepaticfibrosis in rats. Laboratory Investigation 90, 1805-1816

Eissa S and Shoman, S (1998): Tumor Markers, Second Edition, Chapman and Hall, London.

Fallowfield JA, Mizuno M, Kendall TJ, et al. (2007): Scar-associated macrophages are a major source of hepatic matrix metalloproteinase-13 andfacilitate the resolution of murine hepatic fibrosis. J Clin Invest 178:5288-5295

George Kolios, VassilisValatas, Elias Kouroumalis (2006):Role of Kupffer cells in the pathogenesis of liver disease. World J Gastroenterol12(46): 74137420

George Kolios, VassilisValatas, Elias Kouroumalis (2006):Role of Kupffer cells in the pathogenesis of liver disease. World J Gastroenterol14; 12(46): 7413-7420

Giannini EG, Testa R, Savarino V. (2005):Liver enzyme alteration: a guide for clinicians. CMAJ. 172(3):367-79.

Gitnick G,et al.(1992): Diseases of the liver and biliary tract. Mosby-year book. ISBN :0801660750,pp: 145-152

Guyot C, Lepreux S, Combe C, Doudnikoff E, BioulacSage P, Balabaud C, Desmoulière A (2006): Hepatic fibrosis and cirrhosis: the (myo)fibroblastic cell subpopulations involved.Int $\mathbf{J}$ Biochem Cell Biol. 38(2):135-51.

Hsian-Guey Hsieh,Hui-Chun Huang,Fa-Yauh Lee,Cho-Yu Chan, Jing-Yi Lee, Shou-Dong Lee 
(2011):Kinetics of cytokine expression in cirrhotic rats. Journal of the Chinese Medical Association 74

Hsu SM, Raine, L, and Fanger H (1981): A Comparative study of the peroxidaseantiperoxidasee method and an avidin-biotin complex method. Am.J. Clin. Pathol., 75: 734.

Jayashree Bagchi Chakraborty, Fiona Oakley, and Meagan J.Walsh (2012):Mechanisms and Biomarkers of Apoptosis in LiverDisease and Fibrosis. International Journal of HepatologyVolume Article ID 648915, 10 pages

Jonker AM, Dijkhuis FW, Hardonk MJ, Moerkerk P, Kate JT, Grond J. (1994): Immunohistochemicalstydy of hepatic fibrosis induced in rats by multiple galactosamine injections. Hepatology. 19(3):775-781

Koop DR, Klopfenstein B, Iimuro Y, and Thurman RG. (1997): Gadolinium chloride blocks alcoholdependent liver toxicity in rats treated chronically with intragastric alcohol despite the induction of CYP2E1. Mol Pharmacol 51: 944-950.

Koudstaal J, Dijkhuis FWJ, Hardonk MJ. (1991): Selective depletion of Kupffer cells after intravenous injection of gadolinium chloride. In: Wisse E, Knook DL, McCuskey RS, ed. Cells of the hepatic sinusoid. Volume 3. The Netherlands:Kupffer Cell Foundation 87-91.

Lotersztajn S, Julien B, Teixeira-Clerc F, Grenard P, Mallat A. (2005): Hepatic fibrosis: molecular mechanisms and drug targets. Annu Rev Pharmacol Toxicol. 45:605-28.

Mion F, Géloën A, Agosto E, Minaire Y. (1996): Carbon tetrachloride-induced cirrhosis in rats: influence of the acute effects of the toxin on glucose metabolism. Hepatology. 23(3):582-8.

Moss DW and Henderson AR (1999): Clinical Enzymology in: Textbook of clinical chemistry 3rded. Philadelphia, WB Saunders Company. ISBN: 0721656102 ,pp: 617-721.

Naima Z. Mohamed, Howaida I. Abd-Alla, Hanan F. Aly, Mona Mantawy, Nehal Ibrahim, Sohair A. Hassan (2014): CCl4-induced hepatonephrotoxicity: protective effect of nutraceuticalon inflammatory factors and antioxidativeWilliam M. Lee, (2003): DrugInduced Hepatotoxicity. N Engl J Med; 349:474485

Navarro VJ and Senior JR (2006): Drug-related hepatotoxicity. N EngI J Med 354 (7): 731-9

Paduraru I, Saramet A, DanilaGh, Nichifor M, Jerca L, Iacobovici A, et al.(1996): Antioxidant action of a new flavonic derivative in acute carbon tetrachloride intoxication. Eur J Drug MetabPharmacokinet 21: 1-6.

Reyes-Gordillo K, Muriel P, Castañeda-Hernández G, Favari L. (2007):Pharmacokinetics of diclofenac in rats intoxicated with $\mathrm{CCL}_{4}$, and in the regenerating liver. Biopharm Drug Dispos. 28(8):415-22.

Rivera CA, Bradford BU, Hunt KJ, Adachi Y, Schrum LW, Koop DR, Burchardt ER, Rippe RA, Thurman RG. (2001):Attenuation of $\mathrm{CCl}(4)$-induced hepatic fibrosis by $\mathrm{GdCl}(3)$ treatment or dietary glycine. Am J PhysiolGastrointest Liver Physiol. 281(1):G2007.

Rivera CA, Bradford BU, Hunt KJ, Adachi Y, Schrum LW, Koop DR, et al. (2001): Attenuation of CCl(4)induced hepatic fibrosis by $\mathrm{GdCl}(3)$ treatment or dietary glycine. Am J Physiol Gastrointest Liver Physiol 281: G200-207.

Robert C.OH and Thomas R.Hustead (2011): Causes and evaluation of midly elevated liver transaminase levels. Am Fam Physician 84 (9): 1003-1008

Robert Domitrović, HrvojeJakovac,JelenaTomac, IvanaŠain(2009): Liver fibrosis in mice induced by carbon tetrachloride and its reversion by luteolin. Toxicology and Applied Pharmacology 241, 311321

Rose ML, Bradford BU, Germolec DR, Lin M, Tsukamoto H, Thurman RG. (2001): Gadolinium chloride-induced hepatocyte proliferation is prevented by antibodies to tumor necrosis factor alpha.ToxicolApplPharmacol. 1;170(1):39-45.

Rose ML, Bradford BU, Germolec DR, Lin M, Tsukamoto H, Thurman RG. (2001): Gadolinium chloride-induced hepatocyte proliferation is prevented by antibodies to tumor necrosis factor alpha.ToxicolApplPharmacol. 1;170(1):39-45.

Rothschild MA, Oratz M, Schreiber SS. (1972):Effects of carbon tetrachloride on albumin synthesis. J Clin Invest51(9):2310-4.

Ruth A. Roberts,Patricia E. Ganey, Cynthia Ju, Lisa M. Kamendulis, Ivan Rusyn‘and James E. Klaunig (2007): Role of the Kupffer Cell in Mediating Hepatic Toxicity and CarcinogenesisToxicological sciences 96(1), 2-15

SemihaNoyan,IlkinCavusoglu,F. ZehraMinbay (2006):the effect of vitamin A on CCl4-induced hepatic injuries in rats: a histochemical, immunohistochemical and ultrastructural study. ActaHistochemicaVolume 107, Issue 6, Pages 421434

Shukla A and Bhatia SJ (2010): Outcome of patients with primary hepatic venous obstruction treated with anticoagulant alone. Indian J Gastroentrol 29 (1): $8-11$

Thnaian Althnaian, Ibrahim Albokhadaim, and Sabry M El-Bah (2013):Biochemical and histopathological study in rats intoxicated with carbon tetrachloride and treated with camel milk. Springer plus. 2: 57.

Tsukamoto H, Rippe R, Niemela O, Lin M (1995): Role of oxidative stress in activation of Kupffer and Ito 
cells in liver fibrogensis. J Gastroenterol Hepatol 10 SuppL 1:S50-3

Xidakis C, Ljumovic D, Manousou P, Notas G, Valatas V, Kolios G, Kouroumalis E. (2005):Production of pro- and anti-fibrotic agents by rat Kupffer cells; the effect of octreotide.Dig Dis Sci. 50(5):935-41.

Y. Aniya, T. Koyama, C. Miyagi et al., (2005): "Free radical scavenging and hepatoprotective actions of the medicinal herb, Crossocephalumcrepidioides from the Okinawa Islands. Biological and Pharmaceutical Bulletin, vol. 28, no. 1, pp. 1923status in rat Journal of Applied Pharmaceutical Science Vol. 4 (02), pp. 087-100
Yadav, N.P., A. Pal, K. Shanker, D.U. Bawankule, A. K. Gupta, M.P. Dorakar, dan S.P.S Khanuja, (2008): Synergistic Effect of SilymarindanStandarized Phyllanthusamarusagaints Hepatotoxicity in Extract of CCl4-induced Phytomedicine,15, 1053-1061.

Zimmerman, S.W., D.H. Norback and K. Powers (1983): Carbon tetrachloridenephrotoxicity in rats with reduced renal mass. Arch. Pathol. Lab. Med. 107, 264-269.

$$
\begin{aligned}
& \text { عنوان البحث: التاثير الرجعي لماده الجادولينيوم كلوريد علي تلبف الكبد الناتج عن اعطاء ماده الكربون } \\
& \text { تثر اكلوريد في الجرزان البيضناء. } \\
& \text { مني جابر درويش الحديدي1 و محمود محمد الالفي² عمر مدحت عباس3 و فايزه رشاد المنباوي4 و جاد المولي عبد العزيز5 } \\
& 2
\end{aligned}
$$

ان تليف الكبد من الامر اض المسببه للوفاه علي مستوي العالم. و تليف الكبد من الامر اض التي لها خاصيه العلاج الذاتي و

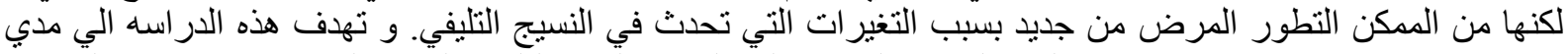

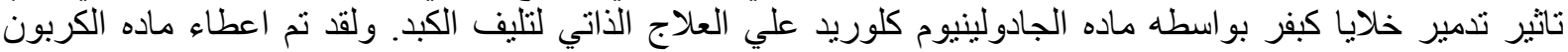

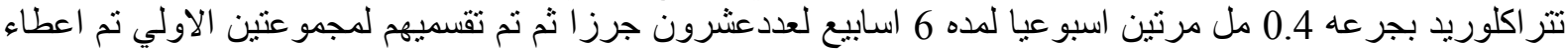

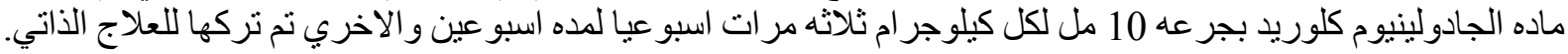

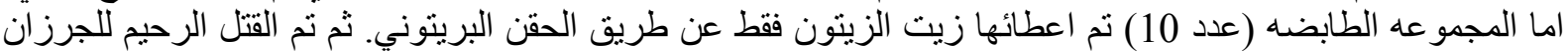

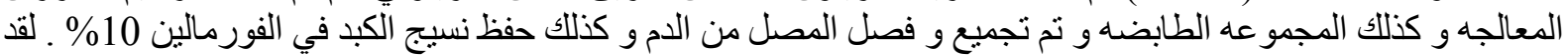

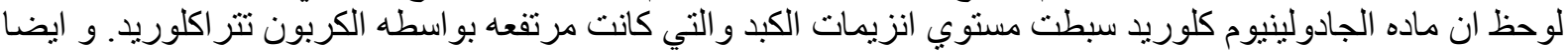

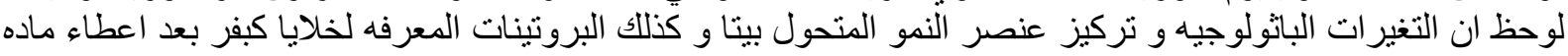

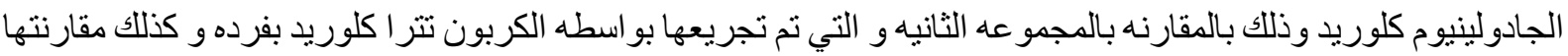

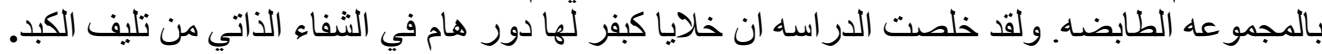

